\title{
Flinders University
}

\section{Gay Lynch}

\section{Writers Barnstorm Postgraduate Creative Writing Schools}

\section{Introduction}

Postgraduate creative writing has taken off and the candidates are under scrutiny: first-class passengers carrying literary gongs and impressive publication lists; business-class passengers with professional writing backgrounds in journalism and literary bureaucracy; economy-class passengers returning midlife from the world of work and carrying small publication records (a book, short stories, some poems); and student concession passengers fresh from Honours. This paper will argue that while all these groups enrich and diversify the creative writing cohort, economy-class passengers, focused and requiring little in-flight service, are value-added.

Will these 35- to 55-year-olds (roughly, baby boomers), competing successfully for places against less experienced applicants, raise the ire of ageist critics? Drusilla Modjeska's thoughtful essay on the next generation of 'public intellectuals,' and whether they will have a craft to board, acknowledges this tension:

Think of the bad blood between boomers and the halfgeneration younger that has resented boomers' numbers and their disinclination to die off (They've got a point). (Modjeska 2006: 45)

Will ticketing the economy-class writers change the nature of creative writing and research? Should their publication records weigh against the brilliant potential of young Honours graduates? Are university creative writing programs contested sites where young and old, heads of family and dependent children, academics and fiction writers, professionals and aspirants, teachers and learners squabble over payments for hastily constructed package deals? Post English Department flight service, will ageing $\mathrm{PhDs}$ snoozing in the transit lounge, on their way to private airports in colonial locations, exacerbate teaching shortages?

This paper will suggest that offering postgraduate university places to passengers returning midlife from the world of work, and carrying small publication records, won't precipitate much bad but a great deal of good, and that in any case, a diverse cohort of creative writers sits well with universities' fundamental social justice tenets. At Flinders University, as with many Australian universities, commitment to equity, equal opportunity and cultural diversity are embedded in its Statement of Intent: 
Flinders University operates within a culturally diverse society and recognises that each student and staff member brings their own unique capabilities, experiences and characteristics to the study or work environment. (Flinders University 2002)

In line with this belief, Flinders recognises 'relevant work experience' as an alternative criterion for postgraduate degrees by coursework or research.

In addition to ethical reasons for including economy-class passengers, there are financial ones. Economy-class writers have already demonstrated their productivity. Offered doctoral places, they will continue publishing where they can, earning points and kudos for their cash-converting carrier. The creative writing budget airline has gazumped more than its market share of English and is now well and truly under surveillance for funding, research rigour, acumen and cultural capital. This paper will suggest the benefits - economic, pedagogic and strategic - of reserving seats, a fair share at least, for economy-class creative writing postgraduates.

\section{Traditional Flight Paths}

Brian Edwards of Deakin University reminds us that 'Traditionally postgraduates were young (under 25), male, full-time on campus, on scholarship, and building an academic career path' (Edwards 2002). The connection between this demographic group and old-boy English department networks suggests another paper. Perhaps young men might argue that the mentoring of young women also bears examination.

Nevertheless, opportunities remain, for young men and young women. University creative writing programs, particularly undergraduate, have paved the way for more precocious publication in university anthologies, in performance and published poetry, and in online journals. Outside the academy, successful publication in magazines such as Voiceworks (dedicated to writers under 25), and shortlistings for the Australian/Vogel Literary Award for under-35s, enhance young writers' applications. This paper does not underplay the value and contribution of younger student concession passengers (who are not always less experienced), nor does it set them up as oppositional voices.

The AAWP Guide to Australian and New Zealand University Writing Programs (AAWP 2006) does not, at this point, record numbers of creative writing students, nor break them down by age or gender. However, it is well attested that mature-age entrants are significant players in a massive worldwide increase in postgraduate students (Edwards 2002). Department of Education, Science and Training (DEST) confirms growing numbers of 30- to 49-year-old candidates commencing doctorates by research - 44\% of the total $\mathrm{PhD}$ population in 2005 (calculated from DEST 2005: SHES Table 1). DEST doesn't keep specific data on creative writers within Creative Arts or English $\mathrm{PhD}$ groups, nor distribute them by age. It is reasonable to extrapolate these figures into creative writing groups.

In the research year of my Masters of Creative Writing, taken at Adelaide University in 2003, two students of the eight are under 30. In my 2004 cohort of 20 Flinders University creative writing postgraduates, one candidate is under 30 years of age; during 2005 and 2006 two young men arrive in my $\mathrm{PhD}$ group, both under the age of 30, and four mature-aged 
candidates. I have no way of knowing whether this picture is typical, until analysis of the distribution by gender, age and writing experience of creative writing postgraduates in Australian tertiary institutions has been done.

While there are disparate entry points for postgraduate creative writers, requirements for Masters and $\mathrm{PhD}$ courses in Australian universities offering more flexible accreditation facilitate the convergence of flight paths common to economy-class passengers: submission experience and drafts of sustained pieces of work, publication, and professional writing backgrounds. Creative writing is distinct from traditional disciplines (notably the sciences), although not from other creative areas (drama, journalism and media production, for instance) in valuing life experience and accepting praxis as research.

\section{Literary In-Flight Menus}

'Literary fiction', rechauffe or not, is served on most English and creative writing routes. Despite this, Nicholas Jose, Professor of Creative Writing at Adelaide University, believes that, 'Australian literary fiction is in a critically weakened state' (Jose 2005). Rosemary Neill canvasses this point of view among authors, agents, and publishers, identifying the perceived causes to be the timidity of global publishing, and its use of Nielson's BookScan to constrict local lists (Neill 2005: 5). Academic and author Mark Davis' research suggests that 'the number of home-grown literary novels produced by Australian mainstream publishers has almost halved since the mid-1990s' and that 'such companies (global) tend not to see themselves as custodians of national literary cultures' (Neill 2006: 5). Michael Webster, BookScan's national chairman, admits ready access to sales statistics 'has adversely affected the market for literary fiction' (Neill 2006: 5).

Economy-class postgraduates, experienced and published, will uphold the validity of a range of creative writing genres not presently favoured by mainstream carriers. And while not all of them are aspiring literary fiction writers blacklisted by commercial airlines, nevertheless some are, and where better or more traditional places than universities to cloister and nurture them?

\section{Who Should Get a Boarding Pass?}

It is widely accepted that $\mathrm{PhDs}$ are increasingly mandatory for academic teaching jobs. Economy-class writers who fail to glide directly from Honours to a $\mathrm{PhD}$, a group that includes professional workers from other fields, and who have been accepted for Masters stopovers on the basis of equivalent work, will require money for the fare. Masters and Honours pathways to a $\mathrm{PhD}$ incur fees. Limited and competitive HECS-deferred places require the candidate to remain below low-income thresholds. This is a disincentive for economy-class professionals (writing or other) involved in extra-curricula work.

Despite systemic contradictions, including maintaining adequate supervisory staffing levels and dedicated places for overseas and feepaying candidates, offers of $\mathrm{PhD}$ positions are awarded on merit and, in the case of Australian students, do not incur fees. Although some first- 
class writers refuse scholarships to avoid compromising their income tax, economy-class writers, with little or no income from their publications, will find $\mathrm{PhDs}$ and their attendant scholarships attractive. Age does not disbar them; nor should it. Internecine warfare between the generations over financial support can't be easily resolved. Old or young, paying their way, or supporting their own high-flying children, all writers need to budget for their higher degree.

\section{Economy-Class Passengers: Diversity}

Exciting and original work can spring from an indeterminate and broad base - from life experience. Economist Richard Florida believes creativity to be the vital factor determining economic growth. 'It defies gender, race, ethnicity, sexual orientation, and outward appearance,' he asserts. 'Diversity is not merely enjoyable; it is essential' (Florida 2005: 35). Economy-class writers bring their collaborative relationships with industry including, for example, the arts (films and exhibitions, reviewing magazines, publishing companies and writers-in-residence programs); and can subsequently offer penetrating community promotion of the university program.

Manuscripts developed in universities carrying a diverse list of creative writing passengers will outline 'Other' journeys, apart from

Bildungsroman. Economy-class writers have flown in from left field. In their earlier life, some have bailed out of universities because of problems or commitments arising from their race or disability, gender or sexuality, age or socio-economic status, and non-urban or provincial city isolation. Negotiation of such obstacles can enrich their writing. 'Exciting and valuable creative writing tends to map out the unexamined, the undetermined, and the unfavoured in the culture,' concurs academic Nigel Krauth (Krauth 2001).

\section{Student Concession Passengers Versus Baby Boomers (economy class writers)}

Youth does not predominate in writing cultures. Mature creative writers can still find a market for their work - to a point, the submitting author is invisible and not subjected to physical scrutiny - or a place in the 'created synthetic arts communities of funds, administrators, writers centres, festival organisers editors of "little magazines" with imaginary circulations .... and poets, poets, everywhere,' listed by former member of the Australia Council Literature Board, Frank Devine (cited Moorhouse 2006a), and which he argues spring from public funding. This view concurs with that of Jennifer Webb, academic and editor of TEXT, who is quoted in a subsequent Moorhouse article (one of a series of three) on Australian creative writing (Moorhouse 2006b). Concerns about vocations for mature candidates are being preempted by the Howard Liberal government's tax disincentives for early retirement, and an impending skilled labour shortage. Economy-class writers may be encouraged to stay in the workforce until after the age of 60 to benefit from the abolition of end taxes on their superannuation, and enjoy a change in employment. Options will be limited by the availability of permanent work in their field.

Nevertheless, the media delight in reporting antagonistic ageism. While not specifically targeting creative writing, Mark Davis (Gangland 1999) 
and Ryan Heath (Please Just $F^{*}$ ck Off: It's Our Turn Now 2005) vigorously argue that young Australian careerists have been disenfranchised. In his introduction to Gangland, Davis claims he has not set out to attack baby boomers, but that it is 'their assumption of privilege, not their date of birth that will be held against them' (Davis 1999: x). Later in the book he amplifies his intergenerational plea for social justice, believing that baby boomers have benefited not only from free education, courtesy of the Whitlam government, but by toadying and networking, and in this way they have constructed a bottleneck for aspiring young professionals. In 2005 Heath takes up Davis' argument, suggesting that the bitter and disenfranchised Generation X has flown offshore. Whether this is so deserves closer analysis and is in fact currently being debated, by newspaper and magazine journalists, and bloggers: Googling 'Ryan Heath' and 'Baby Boomers' currently generates more than 67,000 links.

Davis and Heath make no close analysis of other factors, such as gender, race, ethnicity, or sexual orientation, relevant to late postgraduate entry. Age is the focus of their consideration. Heath discusses universities largely in relation to HECS places. Here is his snapshot of Sydney University students catching the train at Redfern Station:

[N]ervous geeks, over-stylised Cosmo readers, the determined and focused first-generation Australians, the part-time students late because they've just dropped the kids off at school or childcare, and the academic types in black jeans who look like they have just entered the 1980s. (Heath 2006: 101)

Given the thesis of his book, it is reasonable to conclude that the students he describes - requiring childcare, wearing dated clothing, and first generation Australians - fall within the age demographic of economy-class writers. His dismissal of members of these groups as 'interesting, diverse, determined,' but 'not the faces of protest and revolt', reflects the political focus of his book. He concludes with a checklist titled, 'How we will know things have changed?' The fourth item of eleven states: 'There will be a string of Cabinets where women and people from ethnic, racial and sexual minorities aren't the odd ones out' (Heath 2006: 213). This concession could be extrapolated to afford affirmative action for previously disadvantaged mature-aged creative writers, but this intention seems unlikely; they are not the focus of his concern. The publication of Davis's latest research is imminent, and will throw new light in the cabin.

In discussing 'young' (my emphasis) writers who applied for a course developing skills in 'writing out' (closing the gap between the academy and the publishing industry) of the University of Sydney, Drusilla Modjeska suggests, 'creative writing students get plenty of this, and in my (possibly jaundiced) view, often don't have a lot to write about. Sophisticated writing, but not much substance' (2006: 43). It makes sense that wider research interests can generate more original creative writing; an example of this is Tessa Gargett's excellent short story, 'Eggs and Beads', which demonstrates her deep involvement in another field (science), and is published in Wet Ink (Gargett 2006: 6). Economy-class writers (those returning midlife from the world of work) are more likely to bring with them skills and understandings from other fields. Resultant diverse questions pursued in texts accompanying creative work will enrich the writers' university praxis, and alert peers with less experience to alternative modes of thinking. The assessment model embraced by most Australian universities offering postgraduate creative writing - creative 
work accompanied by exegesis - encourages the sharing of faculty air space. Flinders University economy-class postgraduate creative writers have forged links with other faculties: history, anthropology, Indigenous and women's studies, theology and social policy, as well as with the engine room, English and literary studies. Some attend classes in cultural theory, others teach.

\section{Women Passengers}

Another paper might explore, with particular reference to economy class, the participation of women in the creative writing cohort. A brief glance at this question suggests women applicants compete well in entering creative arts. In 2003, 180 Australian women commenced doctorates by research in creative arts; almost double the number of men (92) (DEST 2005: SHES, Table 3). Australian Higher Education Report 37, in May 2001 (DETYA 2001), suggests that 'there is no conclusive evidence that either males or females complete at higher rates,' although one study suggests that women take slightly longer (Moses 1994). A paper on gender in postgraduate creative writing programs would need to consider the current political climate in which mature creative and educated women, particularly if they are 'barren' - and this does not refer to a dearth of ideas - are told that they should keep their opinions to themselves.

Two media examples could signify this supposition: the hostility directed at Germaine Greer for daring to critique the late Steve Irwin's environmental legacy - she should just 'put a sock in it' opined Labour minister, Kevin Rudd (Rudd 2006); and conservative columnist Piers Akerman's pontification in the Daily Telegraph, a newspaper with a conservative readership, that Sydney Theatre director Robin Nevin, bemoaning the Prime Minister's lack of interest in the arts, is in the grip of the 'Labour luvvie' lobby and that her remarks echo 'the ditherings' of other 'deluded post-menopausal women' (Akerman 2004: 18). These slight, although provocative, examples of press-fuelled misogyny, in isolation, are merely colourful. Consider by comparison, 62-year-old John Tranter, who has enrolled in a doctorate of creative writing at the University of Wollongong, who is warmly described by Susan Wyndham, in the Sydney Morning Herald, as 'one of Australia's most respected poets', and who 'has joined a growing number of writers studying for postgraduate degrees as a way to fund their work' (Wyndham 2005: 13). It could be concluded that Wyndham's Sydney Morning Herald editorial brief is less antagonistic, and more concerned with fair play, or simply genuflecting to the patriarchy.

In any event, economy-class writers of either sex are not too late to consider a university career path. They may retire later, live better and longer. Short-term contracts in an increasingly casual workforce, while not lucrative, may assist in balancing their writing life. The idea of using $\mathrm{PhDs}$ as de facto literature grants has been discussed by Julienne van Loon and Brian Dibble in TEXT (Van Loon \& Dibble 2004). That the endeavours of creative writing $\mathrm{PhDs}$ add up to more than their creative piece is axiomatic.

Australian universities welcome older writers. The University of Queensland creative writing $\mathrm{PhD}$ webpage opens with: The Doctorate in Creative Writing is designed for professional writers to work on a research and creative project at the doctoral level with a view to an academic 
career in teaching creative and/or professional writing.

Applicants come from a variety of professional backgrounds: writing, publishing, academia, the arts, and people working in the film and television industry. (University of Queensland 2005)

Adelaide University webpage concurs: 'The PhD in Creative Writing attracts writers, and to a very great extent, forms part of their emerging or continued publication track record' (Adelaide University 2006). Anthony Macris, University of Wollongong's head of journalism and creative writing, verifies that his university 'received a rush of applications from mid-career writers after Literature Board grants were announced each year' (Wyndham 2005: 13). Which doesn't mean those applicants are favoured, of course - just that they are making applications if they don't get grants the de facto grants discussed by Julienne van Loon and Brian Dibble (2004).

\section{Writers' Frequent Flyer Points}

There are cheaper, less demanding places than postgraduate creative writing programs for economy-class writers to obtain skills-based writing training. In launching themselves on the rigorous intellectual university journey they show commitment, but they have flown solo, many times. Sustained, solitary activity will not daunt them.

\section{Creative Writing Praxis}

The economy-class writer has already, in some sense at least, created a product accessible to the public; they have published. Unlike 'pure research' in other faculties - although other 'art vocations' can similarly be included - creative writing values praxis as research. In TEXT (Brien 2005), Donna Lee Brien reviews Material Thinking: The Theory and Practice of Creative Research, by Paul Carter, and discusses his view that creative practice, a complex method of materializing ideas, constitutes research. Carter's idea that creative research explores 'the always unfinished process of making and remaking ourselves through our symbolic forms,' will strike a chord with economy class writers (Carter 2004: 13).

New Writing editor and creative writing academic Graeme Harper argues that creative writing theory is distinct from many other sites of knowledge, and that 'Research can be experiential: emotive, dispositional, psychological, heuristic, and the primary mechanism is praxis' (Harper 2005).

Elements of creative research are often bound together - dreams, recurring images, plays on words - in an arcane way. Economy-class writers can confidently unpack them. Australian Higher Education Report 37 suggests that 'Students who have not come through traditional academic paths such as Honours often need opportunities to develop their research knowledge and skills.' While economy-class writers need just as much support as do younger candidates in traditional academic research practice, or even copyediting, this is much less likely to be the case in their creative writing praxis.

\section{Literary and Cultural Theory}

Despite mainstream publishers' privileging of sales, university writers, critics and many readers are interested in the transformation of ideas, the 
culmination of investigations. Early in the debate, Eva Sallis flags the problem of attendant research clumsily embedded in creative texts (Sallis 1999). Potentially, research requirements for the $\mathrm{PhD}$ can change the focus of economy-class writers whose radars, alert to the academy, allow research to hijack rather than inform their work. A weekend book reviewer refers to an author's 'constant dismembering of the moment, compulsive habit of exegesis' (Keneally 2005: R9). Until the commencement of an exegesis, creative writers have never had to declare their theoretical contraband: the co-opted and transformed history, the artless filching that fed their fiction.

Nevertheless, economy-class writers know that deep engagement with their subject, reading, analyzing, interpreting, weighing up truths of one kind or another, will guide their work. The transformation of these materials into art remains a vexed issue. The recent flight of fiction writers into history has resulted in collateral damage: since The Secret River won the 2006 Miles Franklin Award, Kate Grenville has been forced to defend its fiction and its history (Hirst 2006: 10; McKenna 2005: 1); in an article on the 2006 Australian/Vogel Literary Award short list, John Dale, Director of the Centre for New Writing at the University of Technology, Sydney, summarises the judges' conclusion that 'This new wave of Australian writers seem more in touch with contemporary times and less interested in, say, historical fiction,' and that they 'have noticed a welcome return to narrative' (Dale 2006). Connecting these two statements could imply that the judges believe history is fictionalised at the expense of narrative, or that young writers have been scared off the topic, or simply that finalists did not take it up. Historical fiction, often taken up by older writers with family stories to tell, particularly in hybrid genres such as life writing, is a hot potato, and it is to be hoped that Grenville's 2006 Booker shortlisting will put it back on airline menus.

Universities offer access to resource rich networks, which support the research of economy-class creative writers. Gail Jones began writing fiction as a postgraduate and is fast positioning herself, not only as a prizewinning Australian writer of hybrid fiction, but as a research writer who uses, at least in part, her scholarly explorations of the notion of modernity and history to divebomb the human psyche.

Inevitably, academic research will lead economy-class writers into more turbulent space - cultural criticism. If writers have previously published research-based creative writing, researching within the academy will placate their harsher critics. Creative writing can be oblique, elliptical, and multi-voiced. It can create its own mythology and subvert the truths of others, to invite a reader's deep engagement. A more experienced writer knows that while constructing, they must simultaneously interrogate their preoccupations in the work. Reading theory will affirm or abrogate their writerly practice, allowing them to examine the work of scholars writing in their field, and illuminate the shifting meanings of their own.

Literary theorist Pierre Macherey argues that:

Fiction is not truer than illusion; indeed, it cannot usurp the place of knowledge. But it can set illusion in motion by penetrating its insufficiency, by transforming our relationship to ideology. By its nature, ideology is always elsewhere... (Macherey 1978: 64) 


\section{Gay Lynch TEXT Vol 10 No 2}

Less experienced writers reading theory hear only discord until, in time, exclusionist words become signifiers of deep thought and complex ideas, powerful jets for penetrating the fogs and storms obscuring historicity. At university, economy-class writers renew old links, take up new, essentially revivify their practice.

\section{The Exegesis as the Flight Recorder}

Not only does the exegesis provide economy-class writers with an opportunity to write and even publish the trail of vapours leading to their meme, but it allows them to descend slowly through a cloud of obfuscations, all the time tinkering with the engine, while others - peers, supervisors, faculty leaders and refereed journals - deconstruct their craft.

The creative work and the exegesis explore a common question, albeit in disparate mode and language, and each artifact maintains its own discrete integrity. Argues Macherey:

The text is not a tissue of illusions which has merely to be unraveled if we wish to understand its power. An illusion that has been set to work becomes more than a mere deception. It is an illusion interrupted, realized, completely transformed. (1978: 62)

However slight their publication record, economy-class writers have experienced criticism, positive and negative; some pre-flight immunisation has occurred.

If the exegesis is the flight recorder and a safety feature of the creative writing program, it can present a negative image - of crashing out. Its primary purpose is not to justify the selection of the candidate, young or old, nor airlift cheap or shoddy creative writing, and absolve the fatal supervising crew of blame.

\section{Ontological}

Knowledge of themselves and others informs writers' characters. Deep reading, coupled with life experience, enriches writing. Good news for writers who have lived longer, and in exotic places, who are descended from Hussars, or gypsies, or foreign despots, or who have done bad and fascinating things. Economy-class writers are not afraid of peers stealing their ideas. They know that creative writing is drafted and redrafted, invested with ideas and experience, and articulated by each writer's unique voice. Supported in the past by first-class writers, they know that collaboration brings the kind of generosity, which benefits both sides.

Within my cohorts at two Adelaide universities are an ex-private manuscript assessor, someone who ran a business teaching public speaking, three people who work developing scripts for radio and television, performance poets, published writers and speakers, a journalist, a social worker, a counsellor and several teachers. They model good work and creative practice. Responsibility for children and complicated family constellations put pressure on candidates of any age. In Australia, the implementation in 2001 of the Research Training Scheme (RTS) has 'substantially changed the time scale and funding of postgraduate students in Australia' (Edwards 2002). Completing a doctorate on time (within four years) is now real pressure. If supervisors fail to track their students, using comprehensive annual reviews of progress, or to land their planes on time, their universities are economically disadvantaged. Many economy-class writers are parents, teachers and workers. Some have experience in 
management. They can go to sleep in one manuscript and wake up in another. They will be capable of making a cogent plan and, to the degree that any of us have control, restructure their lives around it.

\section{Links with Community and Industry}

Recent newspaper articles attest to the difficulties of getting published when many mainstream publishers no longer accept unsolicited manuscripts. Economy-class writers can share their links with industry (agents, networks and publishers) with the younger writers in their cohort. Involved with professional committees and funding bodies, they bring kudos, attracting new students to the cash-converting university.

In addition, economic rationalist publishing probes are both hyper-reactive and manipulative. According to a correspondent at the 2005 London Book Fair, $95 \%$ of book trade marketing is aimed at under-50s, despite the fact that spending by the over-50s in western Europe has increased three times faster than for any group in recent years ('Page on Age' 2005: BO8).

Perhaps the global publishing behemoths will swing around and economyclass writers will get the opportunity to write for other baby boomers: cashed up, leisured, and literate.

In marketing terms, economy-class writers lack the fresh appeal (although their writing may not) of a younger candidate, working on their first or second sustained piece of writing, but publishing also value writers who have online editing experience. If impoverished universities competing for students are keen to cash in on government incentives (early completion), these writers cannot be overlooked.

\section{Economy-Class Writers' Excess Baggage}

\section{Instabilities in Creative Writing Workshops}

Conversations with economy-class writers suggest that for some, creative writing schools employing workshop models precipitate a drop in altitude. If these passengers feel precious about their atavistic process of creation hard experience will have taught them not to take an undeveloped idea on a virgin flight - they will bide their time, until confident that their manuscript will benefit from feedback offered by their postgraduate workshop group. Early or too savage criticism can warp the creative process.

Successful Australian writer Ian Bone (2005) confirms that in his Masters year, 'I was trying to keep my radar clear when it was receiving a host of other opinions and input that I normally don't have to hear.' Bone sees it as a challenge. While writing in a university differs from developing a contracted manuscript, usually one-on-one, with an editor in the trade, often by email and with a vested interest on each side in real engagement, there are many benefits for the economy-class writer. Supervisors commit to seeing a writer's undeveloped project through; they are, on paper at least, available.

\section{Using the University and Moving On}

University creative writing programs airlift economy-class writers out of the marketplace, buy them time and resources while they develop and research a big, complex idea. Constraining deadlines, progress reports, presentations and workshops produce work. What of writers who refuel at university and fly away? Universities look fraternal, (maternal even) providing scholarships for some and support of a practical kind: editing 
and criticism, regular feedback, texts, including people, peers and mentors. First-class writer passengers are as entitled to these benefits as any other writer; writing, however prized, is notoriously underpaid. 'I chose the one that gave me a scholarship, Wollongong,' confesses poet John Tranter, adding, 'It's good to have someone keep you on track' (Wyndham 2005: 13). Universities must determine which class of passenger will bring returns on their investments, and how active they wish each writer to be, in the university literary milieu.

A view that the creative work and its theoretical accompaniment, the exegesis, suffice as original research in a doctoral context has been shaken by rumbling criticism that the research presented in the exegesis should have currency outside creative writing departments (Hosking 2005: 38). Will this challenge the fast-producing writer, whose published creative work has a tendency to overtake the exegesis? In which case, retrospective documentation of a research question will be redundant. Will the writer drop out or begin again? Less interested in research than in a stimulus for further work, will they fall away; or in seeking licence to supplement their income with university teaching, renegotiate their proposal?

Although economy-class writers have already broken through publishing barriers, university mediation (workshop developing and editing) will improve an unplaced manuscript, and can circumvent premature vilification by literary border police (publishers' readers, for instance). A recent article by Jennifer Sexton in the Weekend Australian describes the rejection by agents and publishers of a masked extract from Patrick White's The Eye of the Storm. Imre Salusinszky, the latest Chair of the Literature Board of the Australia Council, argues that 'Australian readers are only missing out if there are lots of Patrick Whites out there submitting manuscripts that are rejected. But I don't think [there] are. They [publishers] are sent a lot of crap' (cited in Sexton 2006: 21). Ignoring the implications of the 'whiting out' of current lists, Salusinszky's attitude leaves undeveloped manuscripts, even potentially worthy ones, in a permanent holding pattern.

'The standard of work that comes in as unsolicited manuscripts is, as a general rule, extraordinarily low,' agrees Shona Martin, publishing director at HarperCollins, quoted in the same article. She concludes that home word processing has made it too easy for budding writers to knock out a story. HarperCollins runs a mentoring program in which editors mentor 'selected writers' (Martin cited in Sexton 2006: 21). Frank Moorhouse's tripartite series on writing refers to the government funding bodies' responsibility for 'the winnowing of the new crops of emerging talent' (Moorhouse 2006c: 10). This is bleak news for all aspiring writers, including the 900 who entered manuscripts in the 2005 ABC Fiction prize (Tuffield 2006: 26). It could reasonably be presumed these same manuscripts are present in the slush piles of the nation's publishing houses: could they all be 'crap'? A fair case could be made for economy-class writers buying university package deals, and better positioning themselves before the 'winnowing'.

\section{Interruptions from the Publisher}

Will these writers' links with publishers distract them from passing postgraduate flight checks? What do they do when a copyedit is airdropped in at some inopportune time - two weeks before presentation of their proposal, perhaps? How do they make time to deal with blurbs and biographies, covers and layouts, acknowledgments and marketing plans? Getting out a contracted book must come before the writing of another. 
The university has coped with worse. It is difficult to underestimate the impact of outside work commitments on the productivity of student concession passengers.

\section{Employment}

Academic jobs are in short supply, but it is well attested that creative writing is a growth area. Economy-class writers can teach to supplement their income, while writing, and in leaner days. How will they compete for jobs with late submitters, young, male and mobile, busy building their teaching profile? Despite low pay and poor security, many of them will tutor, and teach short-term contracts. Universities benefit by employing even slightly published writers. Such credibility can attract new students, help build a collegiate literary community, and strengthen the university's creative writing program in the marketplace.

\section{Conclusions}

Diversity is strength. Insofar as creative writers don't retire at 40, 50 or 60 , but continue to develop, they are less constrained by age than are candidates in other disciplines. 'A study of the past 50 years of the New York Times bestseller list has revealed that the average age of the authors who made it to the top was 50.5 years' (Young 2005). Australian writers can be heartened by the late literary careers of Jessica Anderson, and Elizabeth Jolley, and the many other writers, including Thea Astley and Colin Thiele, who continued writing well into their 70s. Examples abound of 'elderly' (over 60) overseas writers who continue to surprise and delight critics and the reading public.

Economy-class writers bring diverse skills and life experiences, the most useful being their writing praxis, which will enrich their continued creativity, attendant research, teaching and work shopping, and benefit the university, in many ways. While the university writing pathway is timehonoured, publications can lift its profile. As the English canon morphs into the twenty-first century, literature, new and old, can illuminate thinking and enrich creative work. Contradictions between young and old, writer and critic, product and market, teaching and practice, might smooth out, and we can all get on with business. There are many ways to be a writer, and we must all support each other.

Economy-class creative writers' frequent-flyer-points outweigh their excess luggage.

\section{Works cited}

AAWP Guide to Australian and New Zealand University Writing Programs 2006. http://www.griffith.edu.au/school/art/text/cwcourses.htm Return to text

Adelaide University 2006 'Creative writing at Adelaide - PhD'. http://www.adelaide.edu.au/humss/creativewriting/posrgrad/ (accessed 12/10 06) Return to text

\section{Akerman, Piers 2004 'The art of biting a helping hand', Daily Telegraph, 27 January} Return to text 
Brien, Donna Lee 2005 'Thinking about writing and research: review of Paul Carter, Material thinking: The theory and practice of creative research', TEXT 9.2, October Return to text

Carter, Paul 2004 Material thinking: The theory and practice of creative research, Carlton: Melbourne University Press Return to text

Dale, John 2006 'Pick of the crop', Weekend Australian, 16-17 September Return to text

Davis, Mark 1997 Gangland: Cultural elite and the new generationalism, St Leonards: Allen \& Unwin Return to text

Department of Education Science and Training (DEST) 2005 Selected Higher Education Statistics, 'Commencing students by age group and broad level of course, Table 1'. http://www.dest.gov.au/sectors/higher_education/publications_resources/statistics/ selected_higher_education_statistics/ (accessed 1/5/05, 6/10/05, 19/10/06) Return to text

Department of Education, Training and Youth Affairs (DETYA) 2001, 'Australian higher education report: Factors associated with completion of higher degrees', No 37, May Return to text

Edwards, Brian 2002 'Postgraduate supervision: Is having a PhD enough?', A paper presented at the Australian Association for Research in Education Conference Problematic Futures: Educational Research in an Era of ... Uncertainty Brisbane: 1-5 December. www.aare.edu.au/02pap/edw02382.htm (accessed 1/5/05) Return to text

Flinders University 2002 'Cultural Diversity and Inclusive Practice Statement' www.flinders.edu.au/ppmanual/EqualOpportunity/culturaldiversity.html (accessed 12/10/06) Return to text

Florida, Richard 2005 The flight of the creative class: The new global competition for talent, New York: HarperCollins Return to text

Gargett, Tessa 2006 'Eggs and beads', Wet Ink, Winter, 6 Return to text

Harper, Graeme 2005 Video linkup Flinders University/Portsmouth University, 27 September Return to text

Heath, Ryan 2006 Please just f*ck off it's our turn now: Holding baby boomers to account, North Melbourne: Pluto Press Return to text

Hirst, John 2006 'Forget modern views when bringing up the past', Australian, 20 March Return to text

Hosking, Rick 2005 'Word games: review of Hazel Smith, The writing experiment', Australian Book Review, 38 Return to text

Jose, Nicholas 2005 'Address to Friends of Adelaide University', State Library of South Australia, 14 September Return to text

Keneally, Cath 2005 'Praise of modernity sculpted in hopeless silence: review of Gail Jones, Dreams of Speaking', Weekend Australian, 18-19 February, R9 Return to text

Krauth, Nigel 2001 'The creative writing doctorate in Australia: An initial survey', TEXT 5.1, April Return to text

Macherey, Pierre 1978 A theory of literary production (trans Geoffrey Wall), London: Routledge \& Kegan Paul Return to text

McKenna, Mark 2005 'Writing the past', Australian Financial Review, 16 December Return to text

Modjeska, Drusilla 2006 'Our future thinkers: The search for the next generation of public intellectuals', The Monthly, July, 43-45 Return to text 
Moorhouse, Frank 2006a 'So what the hell has happened to Australian writing?', Weekend Australian, 20 May, 8 Return to text

Moorhouse, Frank 2006b 'How to become a writer', Weekend Australian, 27 May, 10 Return to text

Moorhouse, Frank 2006c 'A nation of scribblers', Weekend Australian, 3 June, Review; Feature Series, 10 Return to text

Moses Ingrid 1994 'Planning for quality in graduate studies', Ortran Zuber-Skerrit and Yoni Ryan (eds) Quality in Postgraduate Education, Kogan Page: London Return to text

Neill, Rosemary 2006 'Who is killing the great books of Australia?', Australian, 18 March, Review: Feature Return to text

'Page on age' 2005 Weekend Australian, 30 April-1 May, B08 Return to text

Rudd, Kevin 2006 'Greer should shut up says Rudd', News.com.au (accessed 6/9/06)

Return to text

Sallis, Eva 1999 'Research fiction', TEXT 3.2, October Return to text

Sexton, Jennifer 2006 'Why bother with Patrick White', Weekend Australian, 15-16 July, Inquirer, 21 Return to text

Tuffield, Aviva 2006 'Small, but perfectly formed', Age, 21 January, A2, 26 Return to text

University of Queensland 2005 'Doctor of Philosophy in creative writing', English, Media Studies and Art History at University of Queensland.

http://www.emsah.uq.edu.au/index.html?page=20427\&pid=20384 (accessed 5/11/05)

Return to text

Van Loon, Julienne and Brian Dibble 2004 'The higher degree research journey as a threelegged race', TEXT 8.2, October Return to text

Wyndham, Susan 2005 'Writers go back to the books', Sydney Morning Herald 5 March Return to text

Young, Bob 2005 cited in Jason Steger 'Mature writers are winners', Bookmarks, Age, Review Section, 21 May: 6 Return to text

Gay Lynch completed her Masters of Creative Writing at Adelaide University in 2004 and is presently teaching English, Fiction For Young Readers, and Creative Writing, at Flinders University, while she works on her PhD. Cleanskin, her first adult novel, is now published.

\section{TEXT}

Vol 10 No 2 October 2006

http://www.griffith.edu.au/school/art/text/

Editors: Nigel Krauth \& Jen Webb

Text@griffith.edu.au 